\title{
Influence of edge defects on Raman spectra of graphene
}

\author{
G. N. Ten ${ }^{1}$, A. Yu. Gerasimenko ${ }^{\dagger, 2,5}$, M. S. Savelyev ${ }^{2,5}$, A. V. Kuksin², \\ P.N. Vasilevsky², E. P. Kitsyuk³, V.I. Baranov ${ }^{4}$ \\ †gerasimenko@bms.zone
}

\begin{abstract}
${ }^{1}$ Saratov State University n. a. N. G. Chernyshevskiy, 155 Moskovskaya St., Saratov, 410026, Russia
${ }^{2}$ National Research University of Electronic Technology, 1 Shokin Sq., Moscow, 124498, Russia

${ }^{3}$ Scientific-Manufacturing Complex “Technological Centre”, 1-7 Shokin Sq., Moscow, 124498, Russia

${ }^{4}$ Vernadsky Institute of Geochemistry and Analytical Chemistry RAS, 19 Kosygina St., Moscow, 119991, Russia

${ }^{5}$ I.M. Sechenov First Moscow State Medical University, 2-4 Bolshaya Pirogovskaya St., Moscow, 119991, Russia
\end{abstract}

The effect of the vacancy edge defect (bonds breaking between carbon atoms) of a graphene sheet on the Raman spectrum was studied. The spectra were calculated using the density functional theory (DFT) using the Gaussian-09 program. Modeling of a graphene sheet fragment with a break of one bond between carbon atoms at the edge showed that changes in the Raman spectrum were common for the presence of nitrogen and oxygen atoms. In this case, the strongest D lines appear in functionalized graphene with oxygen atoms, and the $\mathrm{D}^{\prime}$ lines - in nitrogen-doped graphene. This is confirmed by the experimental Raman spectra as well as calculated ones. The strongest $2 \mathrm{D}$ line is characteristic of the graphene model without impurities; the presence of other oxygen or nitrogen atoms leads to a decrease in its intensity. Modeling of a graphene sheet fragment with a break of one bond between carbon atoms at the edge showed that changes in the spectrum are common for both cases of graphene nitrogen-doping and functionalization with oxygen atoms. A comparison of the experimental data with the simulation results showed good agreement between the data. Moreover, the vibrations of hydrogen atoms linked by covalent bonds with neighboring carbon atoms moved towards each other in disturbed hexagonal structures located on the edge of the graphene sheet. Such a steric effect led to a decrease in the frequency of the stretching vibration $q(\mathrm{CH})$, which appeared in the region of $\sim 2700 \mathrm{~cm}^{-1}$ and corresponded to the $2 \mathrm{D}$ vibration. The results of the vacancy edge defect modeling for the graphene sheet fragment being nitrogen-doped and functionalized by oxygen atoms were compared with experimental data.

Keywords: graphene, density functional theory, Raman spectroscopy, molecular modeling, vacancy defect.

УДК: 535.375 .51

\section{Влияние краевых дефектов на спектр комбинационного рассеяния графена}

\author{
Тен Г.Н. ${ }^{1}$, Герасименко А. Ю. ${ }^{\dagger, 2,}$, Савельев М.С., ${ }^{2,5}$, Куксин А. В. ${ }^{2}$, \\ Василевский П.Н.․, Кицюк Е. П. ${ }^{3}$, Баранов В. И. ${ }^{4}$ \\ ${ }^{1}$ Саратовский государственный университет им. Н. Г. Чернышевского, ул. Московская, 155, Саратов, 410026, Россия \\ ${ }^{2}$ Национальный исследовательский университет «МИЭТ», пл. Шокина, 1, Москва, 124498, Россия \\ ${ }^{3}$ Научно-производственный комплекс «Технологический Центр», пл. Шокина 1-7, Москва, 124498, Россия \\ ${ }^{4}$ Институт геохимии и аналитической химии им. В.И. Вернадского РАН, ул. Косыгина, 19, Москва, 119991, Россия \\ ${ }^{5}$ Первый МГМУ им. И. М. Сеченова Минздрава России, ул. Большая Пироговская, 2-4, Москва, 119991, Россия
}

Исследовано влияние вакансионного краевого дефекта (разрыв связей между атомами углерода) листа графена на спектр комбинационного рассеяния (КР). Расчет спектров был выполнен с помощью теории функционала плотности (DFT) по программе Gaussian-09. Моделирование фрагмента листа графена с разрывом одной связи между атомами углерода на краю показало, что изменения в спектре являются общими для случаев легирования графена атомами азота и функционализации атомами кислорода. При этом как в экспериментальных спектрах КР, так и в рассчитанных наиболее сильные линии D проявляются в функционализированном графене с атомами кислорода, а линии $\mathrm{D}^{\prime}$ - в легированном азотом графене. При этом наиболее сильная линия 2D характерна для модели графена без примесей, а легирование графена азотом или функционализация кислородом приводит 
к понижению её интенсивности. Такое сравнение результатов моделирования с учетом вакансионного краевого дефекта для фрагмента листа графена в виде параллелограмма с атомами водорода, легированного атомами азота и функционализированного атомами кислорода с экспериментальными данными показало хорошее соответствие данных. При этом в нарушенных гексагональных структурах, расположенных на его краю, колебания атомов водорода, связанных ковалентной связью с соседними атомами углерода, движутся навстречу друг другу. Такой стерический эффект приводит к понижению частоты валентного колебания $q(\mathrm{CH})$, которое проявляется в области $\sim 2700 \mathrm{~cm}^{-1}$ и отвечает колебанию 2D. Произведено сравнение результатов моделирования вакансионного краевого дефекта для фрагмента листа графена, легированного атомами азота и функционализированного атомами кислорода с экспериментальными данными.

Ключевые слова: графен, теория функционала плотности, спектроскопия комбинационного рассеяния, молекулярное моделирование, вакансионный дефект.

\section{Introduction}

The use of graphene requires quality control of their manufacture and, very importantly, the diagnosis of structural changes in almost all areas of science and technology. One of the most effective methods for such analysis is the Raman scattering method.

The Raman spectra of graphene have several characteristic bands, which are usually denoted as D, G, D' and 2D bands [1-4]. The presence of the $\mathrm{D}$ band indicates certain defects that can be caused by both imperfection of the crystal lattice and the presence of impurities [5]. Usually the ratio of the intensities of $\mathrm{G}$ and $\mathrm{D}$ bands is determined for quality control [2]. The $\mathrm{D}$ band intensity is several orders of magnitude lower than the $G$ band intensity for samples with a low number of defects [6]. If the intensities of these bands are proportional, the samples have a rather large number of defects.

The nature of the $\mathrm{D}$ band origin is explained by resonance Raman scattering (RRS) at the optical phonon near the K-point of the Brillouin zone $[7,8]$. In defect-free graphene, the resonance scattering process is forbidden by the selection rule, and the $\mathrm{D}$ band is not observed. However, it can be observed in the presence of an additional scattering channel on defects. The calculation and comparison of the $\mathrm{D}$ and 2D bands intensities performed in [9] by the Raman scattering method showed that the intensities of these bands were comparable in the case of defects in the grapheme structure, but the intensities of the $\mathrm{G}$ and $\mathrm{D}^{\prime}$ bands were very low.

Of great interest is the relationship of $\mathrm{D}, \mathrm{D}^{\prime}$, and $2 \mathrm{D}$ bands with each other and with the type of structural defects. In [10], the influence of three types of graphene defects on the ratio of the $\mathrm{D}$ and $\mathrm{D}^{\prime}$ bands intensities was examined, namely: a change in hybridization from $s p^{2}$ to $s p^{3}$, observed due to functionalization or incorporation of atoms into the lattice structure; a change in the shape of graphene edges; creation of vacancies inside the lattice. Pure defective graphene was studied by atomic force microscopy (AFM), and micro Raman spectra were measured using a confocal spectrometer. It has been found that the $\mathrm{D}$ and $\mathrm{D}^{\prime}$ peaks intensity coefficient is maximum $(\sim 13)$ for $s p^{3}$-defects, decreases for vacancy defects $(\sim 7)$, and reaches a minimum for defects at the graphite boundary ( 3.5). Raman spectroscopy is one of the most sensitive methods for determining disorder in $s p^{2}$ carbon materials, since the presence of disorder in $s p^{2}$ hybridized carbon systems leads to resonance in Raman spectra [5].

In this work, the Raman spectrum, based on the data of computer simulation of a graphene sheet fragment in the presence of a vacancy edge defect (bonds breaking between carbon atoms), is calculated. This made it possible to obtain a significant value of the $2 \mathrm{D}$ band intensity, which confirms the effect of this particular defect on the band. The vibrational spectra were calculated by the DFT method at the B3LYP/6-31g(d,p) level using the Gaussian-09 program [11].

\section{Modeling of a graphene sheet fragment with an edge vacancy defect}

For computer modeling, a graphene sheet fragment of a parallelogram shape was chosen (Fig. 1a). This fragment was characterized by Raman spectrum (Fig. 1c) with the G band intensity that was much higher than the $\mathrm{D}$ and $\mathrm{D}^{\prime}$ bands intensities [6]. Hexagon and rhombus shapes are shown in Fig. S1 (Supplementary Material).

To identify the effect of the vacancy edge defect (bonds breaking between carbon atoms), modeling of the other types of defects was performed. Namely, the vacancy defect inside the graphene sheet and the boundary defect due to the absence of hydrogen atoms (Fig. S2, Supplementary Material). In case of the topological defect such as vacancy defect in the hexagonal structure inside graphene, the intensities of both $\mathrm{D}$ and $\mathrm{D}^{\prime}$ bands increased in Raman spectrum, but the $\mathrm{D}^{\prime}$ band intensity was stronger than the $\mathrm{D}$ band intensity. The absence in hydrogen atoms at the boundary of the graphene sheet (Fig. 1b) led to a strong decrease in the intensities of $\mathrm{G}$ and $\mathrm{D}^{\prime}$ bands in Raman spectrum, where practically only one $\mathrm{D}$ band remained (Fig. $1 \mathrm{~d}$ ). It should be noted that the $2 \mathrm{D}$ band in the region of $2700 \mathrm{~cm}^{-1}$ did not appear in all the above cases.

The main attention in this paper is paid to the vacancy violation of the hexagonal structure, which is located on the edge of the graphene sheet. Fig. 2 shows the region of the defect and the results of computer simulation, which made it possible to study the evolution of the atomic and molecular structures in time and space with different numbers of hydrogen atoms in the environment.

Depending on the environment, which was arbitrary (for example, Fig. 2b), different variants of the structure formation and the $\mathrm{CH}$ bonds formation were obtained (Fig. $2 \mathrm{c}-\mathrm{d}$ ). Note that the diversity of the resulting structural fragments can be quite large due to the fact that the hydrogen and carbon atoms can be located unevenly and in different quantity along the edges of the graphene sheet. 




- Carbon atom Hydrogen atom

a

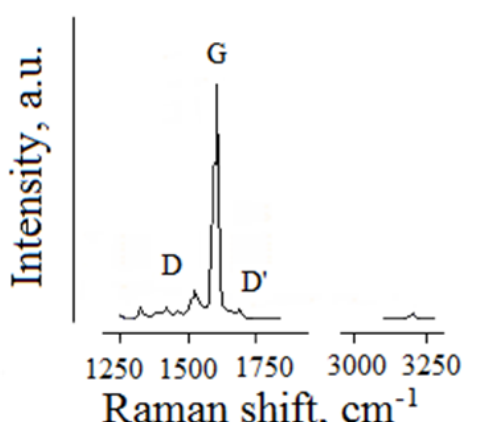

c

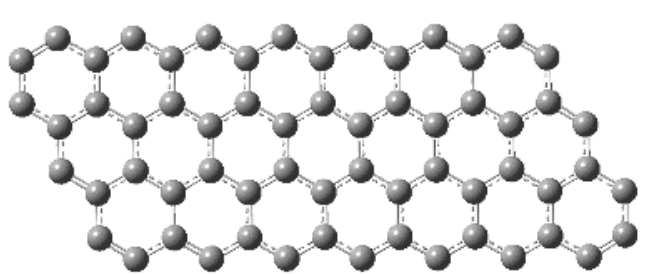

$\mathrm{b}$

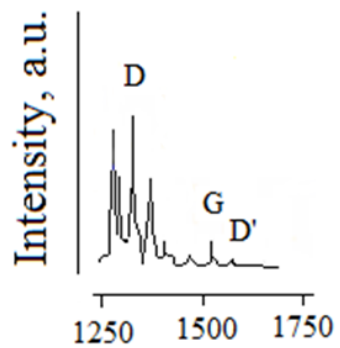

Raman shift, $\mathrm{cm}^{-1}$

d

Fig. 1. Molecular model of a graphene sheet in the form of parallelogram with (a) and without hydrogen atoms (b). Their Raman spectra in the presence of hydrogen (c) and without it (d).



a

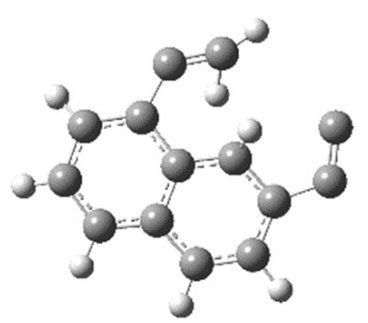

c

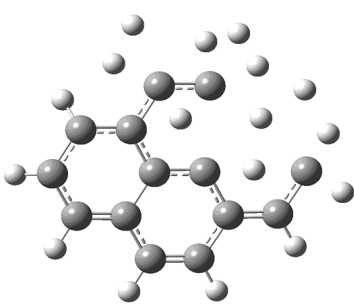

$\mathrm{b}$

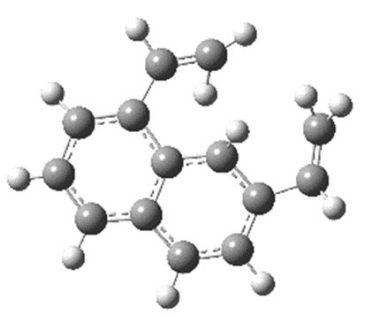

d

Fig. 2. The initial area of the defect (a); example of its environment with hydrogen atoms (b) and results of structure optimization (c,d), which were obtained for different positions of hydrogen atoms near the defect.

\section{Raman spectra of graphene with an edge vacancy defect}

In order to take into account the influence of the presence of nitrogen and oxygen atoms, the Raman spectra were calculated with the presence of at least one vacancy defect in the hexagonal structure, which is located on the edge of the graphene sheet, as well as the presence of nitrogen and oxygen atoms. This fragment was modeled (Fig. $3 \mathrm{a}$ ), doped with nitrogen atoms (Fig. 3 b) and functionalized with oxygen atoms (Fig. 3 c). As experimental Raman spectra, we used the digitized data from published works in which a monolayer of

graphene membrane [3], nitrogen-doped graphene [11], and reduced graphene oxide [12] were studied. The theoretical spectrum was calculated in accordance with the fragment models (Fig. 3d-f).

Common to all structures were steric obstacles that arise during vibrations of hydrogen atoms covalently bonded to neighboring carbon atoms (Fig. 4). In this regard, a decrease in the frequency of the stretching vibration $q(\mathrm{CH})$ was observed, which for all molecular fragments appeared in the region of $\sim 2700 \mathrm{~cm}^{-1}$. On the whole, the theoretical Raman spectra agreed quite well with the experimental spectra. The difference that can be detected was associated with finding several defects with different nature of real graphene at once in the studied field. As well as experimental Raman spectra, the calculated spectra showed the strongest D bands, which appeared in graphene functionalized by oxygen atoms (Fig. 3f), and $\mathrm{D}^{\prime}$ bands - in graphene doped with nitrogen atoms (Fig. 3e). On the contrary, the strongest 2D band was characteristic of model graphene without impurities (Fig. $3 \mathrm{~d}$ ), and doping and functionalization of the graphene sheet led to a decrease in its intensity.

\section{Discussion}

The effect of vacancy defects inside and at the edge of a graphene sheet on the intensities of the $\mathrm{D}, \mathrm{D}^{\prime}$, and $2 \mathrm{D}$ bands is considered in the paper. A feature of the topological defect in the form of vacancies inside the graphene sheet is the excess of the $\mathrm{D}^{\prime}$ band over the $\mathrm{D}$ band (Fig. S2) (Supplementary Material). Therefore, in the case of the ratio $I_{\mathrm{D}^{\prime}}, I_{\mathrm{D}}>1$, the analysis allows one to make a conclusion about the presence of such defects. The $2 \mathrm{D}$ band, as shown in this paper, is associated with the presence of a defect caused by the absence of a carbon atom at the edge of the graphene sheet. Using it, it is possible to obtain qualitative and 


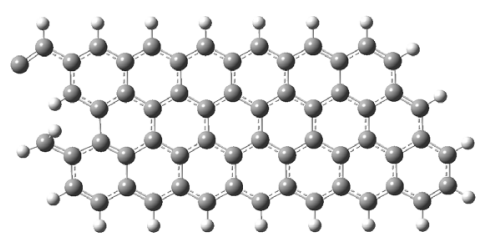

a

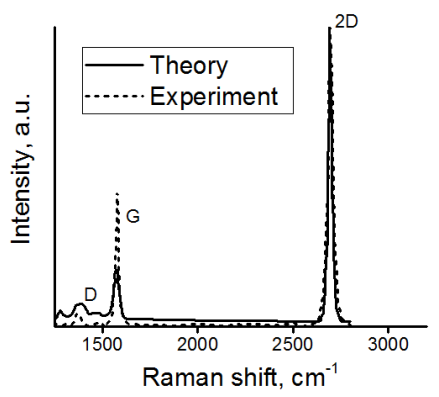

d

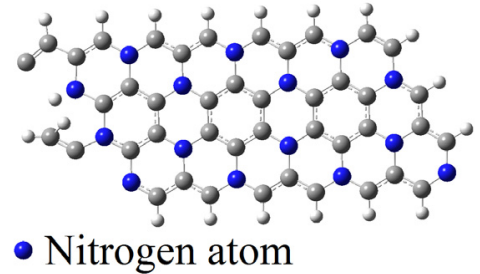

b

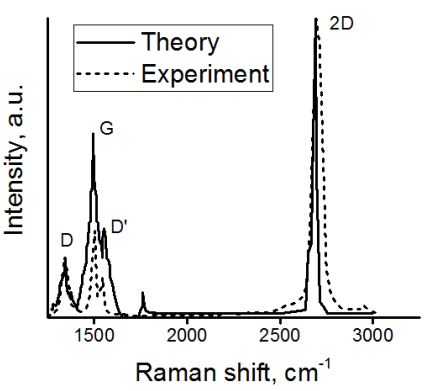



- Oxygen atom

c

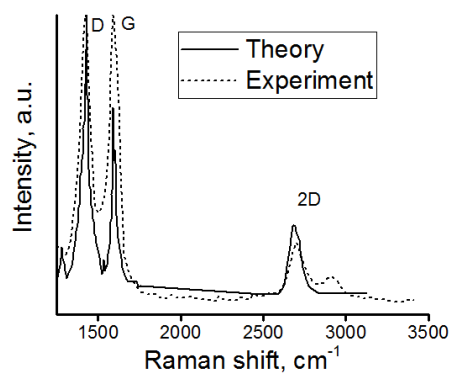

f

Fig. 3. (Color online) Molecular models of graphene sheets with a vacancy defect in the hexagonal structure, which is located on the edge: fragment with the parallelogram shape (a); nitrogen-doped (b) and functionalized by oxygen atoms (c). The following are the theoretical and experimental Raman spectra, respectively: fragment with the parallelogram shape (d); nitrogen-doped (e) and functionalized by oxygen atoms (f).

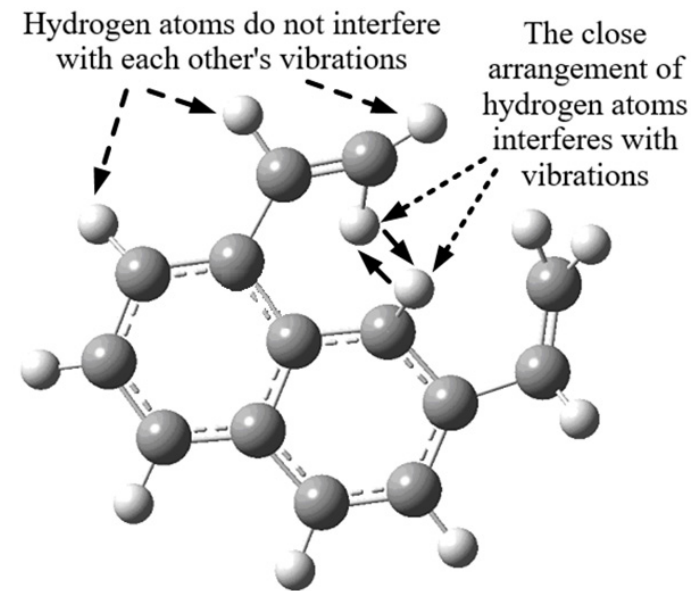

Fig. 4. The region of the defect with hydrogen atoms in the environment, explaining the vibrations.

quantitative information on the process of graphene oxide reduction [13], treatment with ultraviolet radiation [14] or the local number of graphene monolayers [3,15]. An analysis of both $\mathrm{D}^{\prime}$ and $2 \mathrm{D}$ bands is useful in studying the purity of graphene during dehydrogenation [16]. This is possible, since the partial or complete absence of hydrogen atoms at the boundary of the graphene sheet leads to the almost disappearance of $\mathrm{G}$ and $\mathrm{D}^{\prime}$ bands in the Raman spectrum (Fig. 1d), and the presence of nitrogen and oxygen atoms causes a decrease in the intensity of the 2D band (Fig. 2). In case of graphene oxide, the functional groups, such as epoxy (C-O-C), hydroxyl $(\mathrm{C}-\mathrm{OH})$, carbonyl $(\mathrm{C}=\mathrm{O})$ and carboxyl $(\mathrm{COOH})$, can be contained in different quantities [17]. Their presence leads to a decrease in the intensity of the $2 \mathrm{D}$ band, and the intensity of the D band at the same time increases greatly compared to the G band.
The ratio of the intensities of the $\mathrm{G}$ and $2 \mathrm{D}$ bands (Fig. $3 \mathrm{~d}$ ) in the case of an experimental study of graphene can be different depending on the number of monolayers, which is clearly shown by the map of their distribution [17]. After doping with nitrogen (Fig. $3 \mathrm{e}$ ), the D band can exceed $\mathrm{G}$ [18]. This can be explained by a different number of defects inside the sheet or by the partial absence of hydrogen atoms at its edges (Fig. S2, Supplementary Material). During the oxidation of graphene or graphite oxide, not only the contribution from functionalization by oxygen atoms (Fig. 3f) can be observed in Raman spectrum, but also from other groups of atoms with the participation of oxygen and nitrogen, and different concentration of components also affects the Raman spectrum [19]. The quantitative ratio of oxygen and carbon atoms increases the D/G band intensity ratio [20]. Studies of nanoribbons from graphene oxide show that the ratio of these bands is higher than 1 , which also confirms the effect by the shape of the sheet [21].

The data obtained as a result of the Raman spectra analysis can be confirmed by high resolution transmission electron microscopy (TEM) [22]. The image clearly shows vacancy defects located inside the graphene sheet. Moreover, the diversity of the resulting structural fragments can be quite large due to the fact that the hydrogen and carbon atoms, as seen on the TEM, are located unevenly and in different quantity along the edges of the graphene sheet [23]. Edge defects caused by the absence of carbon atom are also clearly visible.

\section{Conclusions}

It was established that the shape of the graphene sheet effects the Raman spectrum, namely, the $\mathrm{D}$ and $\mathrm{D}^{\prime}$ band intensities. The smallest defect effect is observed in the case of the parallelogram shape. In this case, the $G$ band intensity is much higher than the $\mathrm{D}$ and $\mathrm{D}^{\prime}$ band intensities. 
The strongest increase in the $\mathrm{D}$ band intensity compared to the $\mathrm{G}$ band is observed in the case of partial or complete absence of hydrogen atoms at the boundary of the graphene sheet, which leads to the practical disappearance of $G$ and $\mathrm{D}^{\prime}$ bands in the Raman spectrum.

The Raman spectra of one of the most common graphene defects, namely, the breaking of carbon bonds at its edge, were calculated taking into account the possibility of uneven accumulation of carbon and hydrogen atoms.

The molecular modeling shows that a steric obstacle is common for all structural defects on the edge of the grapheme sheet. Such an obstacle occurs during vibrations of neighboring hydrogen atoms moving towards each other. This leads to a decrease in the frequency of stretching vibration $q(\mathrm{CH})$, which manifests in the region of $\sim 2700 \mathrm{~cm}^{-1}$ and corresponds to the $2 \mathrm{D}$ vibration.

Thus, the nature of the $2 \mathrm{D}$ band origin was confirmed by the Raman calculations taking into account edge defects and their coincidence with experimental data for graphene was shown. The existence of such defects in the topological structure is known from the literature $[22,23]$ in accordance with the TEM data.

Supplementary Material. The online version of this paper contains supplementary material available free of charge at the journal's Web site (lettersonmaterials.com).

Acknowledgements. This work was supported by the project of the Ministry of Science and Higher Education of the Russian Federation, project no. 0N59-2019-0017.

\section{References}

1. I. Childres, L. A. Jauregui, W. Park, H. Cao, Y.P. Chen. In: New developments in photon and materials research (ed. by J.I. Jang). Nova Publishers, New York, United States (2013) pp. $403-418$.

2. T. Zhao, Z. Liu, X. Xin, H.-M. Cheng, W. Ren. J. Mater. Sci. Technol. 35 (9), 1996 (2019). Crossref

3. K.-M. Hu, Z.-Y. Xue, Y.-Q. Liu, P.-H. Song, X.-H. Le, B. Peng, H. Yan, Z.-F. Di, J. Xie, L.-W. Lin et al. Carbon N.Y. 152, 233 (2019). Crossref

4. A.Yu. Gerasimenko, E.P. Kitsyuk, A.V. Kuksin, R. M. Ryazanov, A.I. Savitskiy, M.S. Saveliev, A. A. Pavlov. Diam. Relat. Mater. 96, 104 (2019). Crossref

5. A.S. Pawbake, K. K. Mishra, L. G. B. Machuno, R. V. Gelamo, T.R. Ravindran, C.S. Rout, D. J. Late. Diam. Relat. Mater. 84, 146 (2018). $\underline{\text { Crossref }}$
6. M.S. Savelyev, A.Y. Gerasimenko, V.M. Podgaetskii, S. A. Tereshchenko, S. V. Selishchev, A. Y. Tolbin. Opt. Laser Technol. 117, 272 (2019). Crossref

7. E. J. Heller, Y. Yang, L. Kocia, W. Chen, S. Fang, M. Borunda, E. Kaxiras. ACS Nano. 10 (2), 2803 (2016). Crossref

8. P.R. Wallace. Phys. Rev. 71 (9), 622 (1947). Crossref

9. P. Venezuela, M. Lazzeri, F. Mauri. Phys. Rev. B. 84 (3), 035433 (2011). Crossref

10. A. Eckmann, A. Felten, A. Mishchenko, L. Britnell, R. Krupke, K. S. Novoselov, C. Casiraghi. Nano Lett. 12 (8), 3925 (2012). Crossref

11. M.J. Frisch, G.W. Trucks, H.B. Schlegel, G.E. Scuseria, M.A. Robb, J.R. Cheeseman, G. Scalmani, V. Barone, B. Mennucci, G. A. Petersson et al. Gaussian. 09, 394 (2009).

12. H. Gao, L. Song, W. Guo, L. Huang, D. Yang, F. Wang, Y. Zuo, X. Fan, Z. Liu, W. Gao et al. Carbon N. Y. 50 (12), 4476 (2012). Crossref

13. X. Díez-Betriu, S. Álvarez-García, C. Botas, P. Álvarez, J. Sánchez-Marcos, C. Prieto, R. Menéndez, A. de Andrés. J. Mater. Chem. C. 1 (41), 6905 (2013). Crossref

14. M.Z. Iqbal, S. Siddique, A. Rehman. Diam. Relat. Mater. 85, 112 (2018). $\underline{\text { Crossref }}$

15. A.C. Ferrari, J.C. Meyer, V. Scardaci, C. Casiraghi, M. Lazzeri, F. Mauri, S. Piscanec, D. Jiang, K. S. Novoselov, S. Roth et al. Phys. Rev. Lett. 97 (18), 187401 (2006). Crossref

16. Z. Luo, T. Yu, Z. Ni, S. Lim, H. Hu, J. Shang, L. Liu, Z. Shen, J. Lin. J. Phys. Chem. C. 115 (5), 1422 (2011). Crossref

17. A. A. Lebedev, S.P. Lebedev, S. N. Novikov, V.Y. Davydov, A.N. Smirnov, D.P. Litvin, Y.N. Makarov, V.S. Levitskii. Tech. Phys. 61 (3), 453 (2016). $\underline{\text { Crossref }}$

18. R. Beams, L. Gustavo Cançado, L. Novotny. J. Phys. Condens. Matter. 27 (8), 083002 (2015). Crossref

19. S. Zhang, Y. Li, Y. Kang, Y. Dong, S. Hong, X. Chen, J. Zhou, Y.V. Fedoseeva, I.P. Asanov, L. G. Bulusheva et al. Carbon N. Y. 108, 461 (2016). $\underline{\text { Crossref }}$

20. A. A. Babaev, M.E. Zobov, D.Y. Kornilov, S.V. Tkachev, E. I. Terukov, V.S. Levitskii. Opt. Spectrosc. 125 (6), 1014 (2018). Crossref

21. J.A. Velten, J. Carretero-González, E. Castillo-Martínez, J. Bykova, A. Cook, R. Baughman, A. Zakhidov. J. Phys. Chem. C. 115 (50), 25125 (2011). $\underline{\text { Crossref }}$

22. J.C. Meyer, C. Kisielowski, R. Erni, M.D. Rossell, M.F. Crommie, A. Zettl. Nano Lett. 8 (11), 3582 (2008). Crossref

23. C. O. Girit, J. C. Meyer, R. Erni, M. D. Rossell, C. Kisielowski, L. Yang, C.-H. Park, M. F. Crommie, M. L. Cohen, S. G. Louie, A. Zettl. Science. 323 (5922), 1705 (2009). rossref 